\title{
Impact of boundary layer flow velocity on oxygen utilisation in coastal sediments
}

\author{
Stefan Forster*, Markus Huettel, Wiebke Ziebis \\ Max-Planck-Institute for Marine Microbiology, Celsiusstrasse 1, D-28359 Bremen, Germany
}

\begin{abstract}
Small pressure gradients generated by boundary flow-topography interactions cause advective pore water flows in permeable sediments. Advective pore water exchange enhances the flux of solutes between the sediment and the overlying water, thus generating conditions for an increased utilisation of oxygen. We compared a less permeable $\left(k=5 \times 10^{-12} \mathrm{~m}^{2}\right)$ with a permeable sediment $(k=$ $5 \times 10^{-11} \mathrm{~m}^{2}$ ) typical for coastal and shelf sediments. Total oxygen utilisation (TOU) in incubated sediment cores was measured in 10 laboratory experiments using recirculating flow tanks (33 runs). TOU was a function of flow velocity in permeable sediment where advective pore water flow occurred. TOU increased with the increasing volume of sediment flushed with oxygenated water. We found that TOU increased by $91 \pm 23 \%$ in coarse sand when flow increased from 3 to $14 \mathrm{~cm} \mathrm{~s}^{-1}$ (38 mounds $\mathrm{m}^{-2}$. height 10 to $30 \mathrm{~mm}$, flow measured $8 \mathrm{~cm}$ above the sediment). Addition of fresh algal material caused a stronger stimulation of TOU in the coarse sand than in the fine sand ( 4 additional flume runs). After the addition, intensive oxygen consumption reduced the oxygen penetration depth in the advectively flushed zone of the coarse sediment. However, counteracting this process, advective flow maintained an oxic sediment volume still larger than that in the less permeable sediment. Flow-enhanced oxygen utilisation is potentially effective in permeable beds of coastal and shelf regions, in contrast to the situation in cohesive sediments limited by predominantly diffusive oxygen supply
\end{abstract}

KEY WORDS: Oxygen utilisation - Solute transport Permeability - Carbon oxidation - Advection . Sediment topography

\section{INTRODUCTION}

The flux of oxygen across the sediment-water interface accounts for almost the entire remineralisation in deep sea oligotrophic environments (Aller 1990, Rutgers van der Loeff 1990). In coastal and shelf sediments, other respiratory pathways like denitrification, and iron, manganese, and sulphate reduction contribute considerably to the oxidation of carbon (Jørgensen \& Revsbech 1989, Thamdrup et al. 1994). Within the sediments, the reoxidation of the reduced end products occurs to a large extent via oxygen (Canfield et al. 1993, Thamdrup et al. 1994). The total flux of oxygen into the sediment (total oxygen utilisation, TOU) depends on the $\mathrm{O}_{2}$-concentration in the water, the sedimentary organic carbon content available for

•E-mail: stefan@postgate.mpi-mm.uni-bremen.de bacterial metabolism, the concentration of reduced chemical species in the sediment reflecting bacterial activity, and animals present in the sediment.

The sedimentary oxygen uptake is limited by the rate of oxygen transport across the sediment-water interface. Generally, 3 different transport modes may be distinguished: molecular diffusion depending on the existence of concentration gradients, biopumping (irrigation) of oxygenated water by macrofauna through their burrows, and advective pore water flow driven by differential pressure gradients at the sediment-water interface.

Molecular diffusion dominates transport at the sediment surface, in cohesive sediments, in microbial mats and at burrow walls (Aller 1983, Jørgensen \& Revsbech 1985, Revsbech \& Jørgensen 1986), with a diffusive boundary layer often controlling the flux (Gundersen \& Jørgensen 1990, Jørgensen \& Des Marais 1990, Glud et al. 1994). 
Irrigation facilitates flux of solutes across burrow walls, thus affecting solute distribution below the sediment surface (Aller 1983, Kristensen et al. 1985, Forster \& Graf 1992, Marinelli 1994).

Advective transport occurs when biogenic or physical sediment roughness impedes boundary layer flow at the sediment-water interface. Advective pore water flow in the sediment depends on boundary layer flow velocity, on the abundance and shape of topography structures, and the permeability of the sediment (Huettel \& Gust 1992, Ziebis et al. 1996).

In the presence of irrigation, the relative contribution of diffusive oxygen flux across the sediment-water interface to the total amount of oxygen supplied decreases (Lindeboom et al. 1985, Rasmussen \& Jørgensen 1992, Glud et al. 1994, Forster \& Graf 1995). Furthermore, TOU increases after sedimentation of fresh algal material (Hansen \& Blackburn 1992, van Duyl et al. 1992).

In this study, we examined the effect of unidirectional flow on total oxygen utilisation in natural permeable sediments with surface topography. By comparing the measurements of TOU from a highly permeable medium grain sand to those of a fine silty sand with lower permeability, we investigated the magnitude of the stimulation of TOU by pressure-driven advective pore water flow.

\section{METHODS}

Experimental setting. Experiments were conducted in 2 identical flumes (channel length $200 \mathrm{~cm}$, width $30 \mathrm{~cm}$, depth $10 \mathrm{~cm}$ ) recirculating $160 \mathrm{l}$ of sea water. A schematic of the flume design is given in Huettel et al. (1996a). A natural sediment core with a volume of $36 \mathrm{dm}^{3}$ (core size $60 \times 30 \times 20 \mathrm{~cm}, \mathrm{l} \times \mathrm{w} \times \mathrm{h}$ ) was placed within each flume channel. A $1 \mathrm{~cm}$ thick layer of sediment covered the acrylic sheet between the collimators at the up-and downstream end of the channel and the sediment core. Water depth was $10 \mathrm{~cm}$. The propellerdriven free flow velocity was calibrated against the voltage of the motor using neutrally buoyant swimmers at the water surface $(\mathrm{r}=0.987, \mathrm{n}=18)$ and corre- sponded well to flow sensor measurements (Huettel et al. 1996b). Free flow velocities were set between 2 and $14 \mathrm{~cm} \mathrm{~s}^{-1}$. At these velocities, the open channel flow in our flumes was turbulent, with Reynolds numbers ranging from 5000 to 30000 (Giles 1976). Temperature was controlled and regulated through an external cooling unit and oxygen concentration in the water was monitored with an oxygen electrode (WTW 90)

Sediments were collected from 2 locations (Table 1) and left to equilibrate for $6 \mathrm{wk}$. Sand from the nearshore sublittoral off Giglio Island, Italy, in the Mediterranean Sea (Ziebis et al. 1996), below referred to as 'coarse' permeable sediment, was used in experiments performed in Flume 1. Flume 2 contained the less permeable sediment from an intertidal sand flat at Sahlenburg, Germany, at the North Sea, referred to as 'fine' sediment. An overview of the experiments performed in the 2 flumes is given in Table 2 .

Sea water was collected at the North Sea tidal flats, filtered for removal of planktonic algae, and salinity adjusted to $35 \%$ by addition of artificial sea salt, if needed (compare Table 3 ).

Oxygen profiles were measured using micro-manipulator operated microelectrodes equipped with a guard electrode (Revsbech 1989) with a stirring sensitivity $<1 \%$. A 2 -point calibration was made between the anoxic sediment layer and the overlying water. The steepest slope of the concentration gradient ( $\mu \mathrm{M} \mathrm{mm}^{-1}$ ) at the sediment-water interface and the penetration depth of oxygen were used for comparison of profiles at the smooth sediment surfaces.

Permeabilities of both sediments were measured with a constant head permeameter (Means \& Parcher 1964) using cores taken from the flumes after the experiments. We calculated sand grain surface area for both types of sediment from data of grain size distribution according to the Wentworth scale $(<63,<125$, $<250,<500,<1000$, and $\geq 1000 \mu \mathrm{m}$ ) by dry sieving and assuming spherical geometry. Water content and loss on ignition $\left(\mathrm{C}_{\text {org }}\right.$ ) were determined from samples dried at $60^{\circ} \mathrm{C}$ for $24 \mathrm{~h}$ and heated at $550^{\circ} \mathrm{C}$ overnight.

The macrofauna in the Mediterranean sediment was dominated by a thalassinidean shrimp (Callianassa truncata, 22 ind $\mathrm{m}^{-2}$ ) and the North Sea sediment

Table 1 Characteristics of the fine and coarse sandy sediment used in this study. Grain size distribution is given with the first. second and third weight quartile

\begin{tabular}{|c|c|c|c|c|c|c|}
\hline \multirow{2}{*}{$\begin{array}{l}\text { Sediment type } \\
\text { Origin }\end{array}$} & \multirow[t]{2}{*}{ Porosity } & \multicolumn{3}{|c|}{ Grain size distribution $(\mu \mathrm{m})$} & \multirow{2}{*}{$\begin{array}{c}\text { Permeability } \\
\mathrm{m}^{2}\end{array}$} & \multirow{2}{*}{$\begin{array}{c}\mathrm{C}_{\text {org }} \\
(\% \text { dry wt) }\end{array}$} \\
\hline & & $Q_{1}$ & $Q_{2}$ & $Q_{3}$ & & \\
\hline \multicolumn{7}{|l|}{ Silty fine sand } \\
\hline Sahlenburg, Germany, North Sea & 0.4 & 130 & 200 & 320 & $5 \times 10^{-12}$ & 1.2 \\
\hline \multicolumn{7}{|l|}{ Coarse sand } \\
\hline Giglio Island, Italy, Mediterranean Sea & 0.4 & 270 & 350 & 450 & $5 \times 10^{-11}$ & 0.8 \\
\hline
\end{tabular}


by polychaetes (Heteromastus filiformis, Scoloplos armiger). Sediment cores were allowed to equilibrate for $4 \mathrm{wk}$ in the flumes at in situ temperatures in the dark $\left(20 \pm 1\right.$ and $12 \pm 1^{\circ} \mathrm{C}$, respectively). During this period, the shrimps produced a distinct topography ('natural topography') on the sediment surface composed of mounds ( $22 \mathrm{~m}^{-2}$, height 1 to $3 \mathrm{~cm}$ ) and funnels (44 $\mathrm{m}^{-2}$, depth $1 \mathrm{~cm}$ ). Infauna in the intertidal North

Table 2. Experiments carried out in this study. Two identical flumes containing 1 sediment type each were used, both with and without (controls) topography structures

\begin{tabular}{|c|c|}
\hline $\begin{array}{l}\text { Flume } 1 \\
\text { Coarse } \\
\text { Giglio sediment }\end{array}$ & $\begin{array}{c}\text { Flume } 2 \\
\text { Fine } \\
\text { North Sea sediment }\end{array}$ \\
\hline \multicolumn{2}{|c|}{ Dye penetration experiments } \\
\hline 1 run with topography & 1 run with topography \\
\hline \multicolumn{2}{|c|}{ Total oxygen uptake (TOU) } \\
\hline \multicolumn{2}{|l|}{ Expt $1.1,5$ runs with natural topography } \\
\hline \multicolumn{2}{|l|}{ Expt $1.2,7$ runs with natural topography } \\
\hline Expt $1.3,8$ runs with artificial topography & Expt $2.3,5$ runs with artificial topography \\
\hline Expt $1.4,4$ runs with smooth surface (control) & Expt 2.4,4 runs with smooth surface (control) \\
\hline \multicolumn{2}{|c|}{ Total oxygen uptake after addition of algae } \\
\hline Expt $1.5,1$ run with artificial topography & Expt $2.5,1$ run with artificial topography \\
\hline Expt $1.6,1$ run with acrylic sheet, control & \\
\hline Expt $1.7,1$ run with smooth surface (control) & \\
\hline
\end{tabular}

Table 3. Experimental conditions for the measurement of total oxygen utilisation, including number of runs in each experiment, the range of free flow velocities in the runs performed, mass of particulate organic carbon (POC) added, temperature, salinity, and abundance, dimensions, and type (A: artificial; N: natural) of surface topography structures present

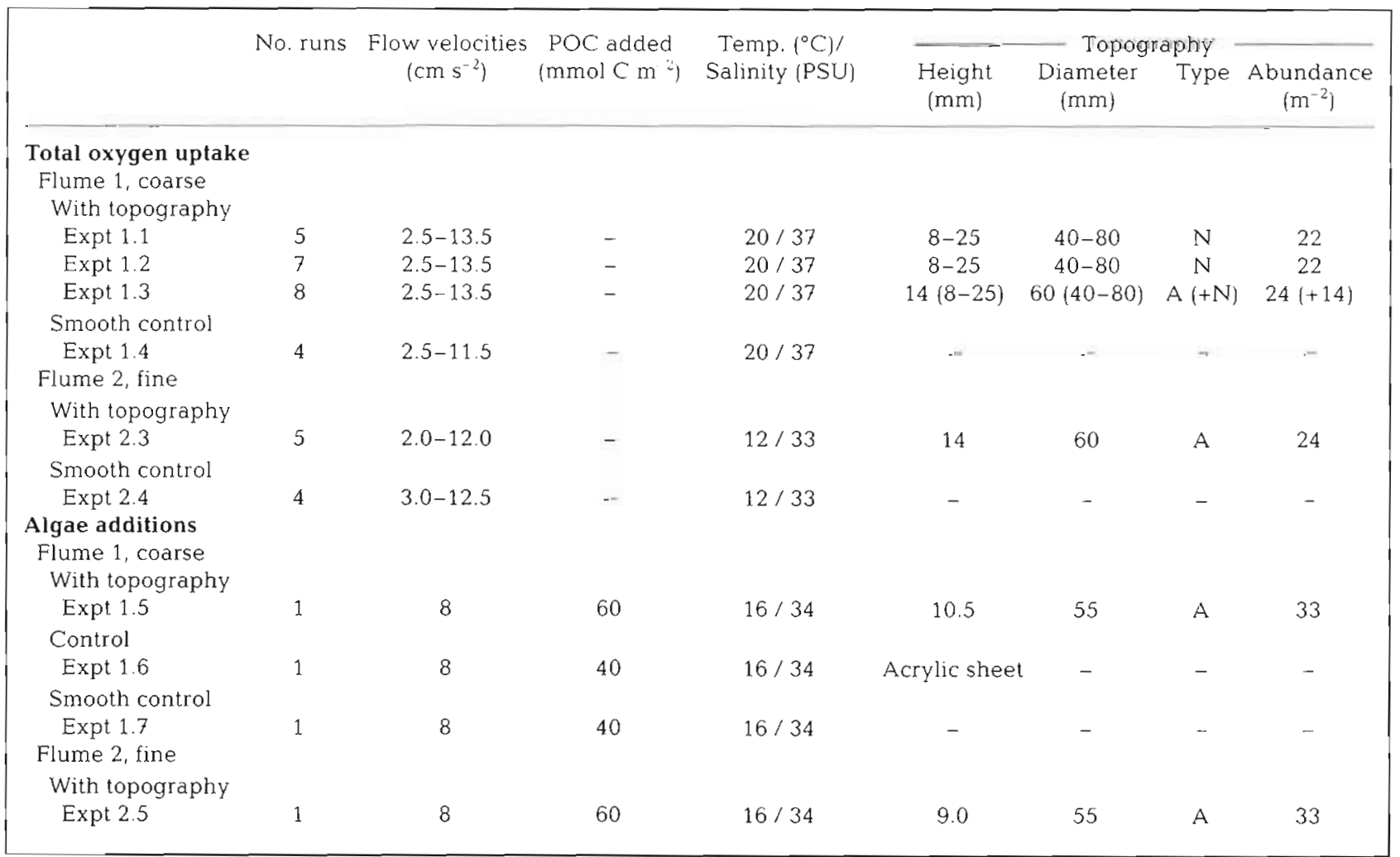




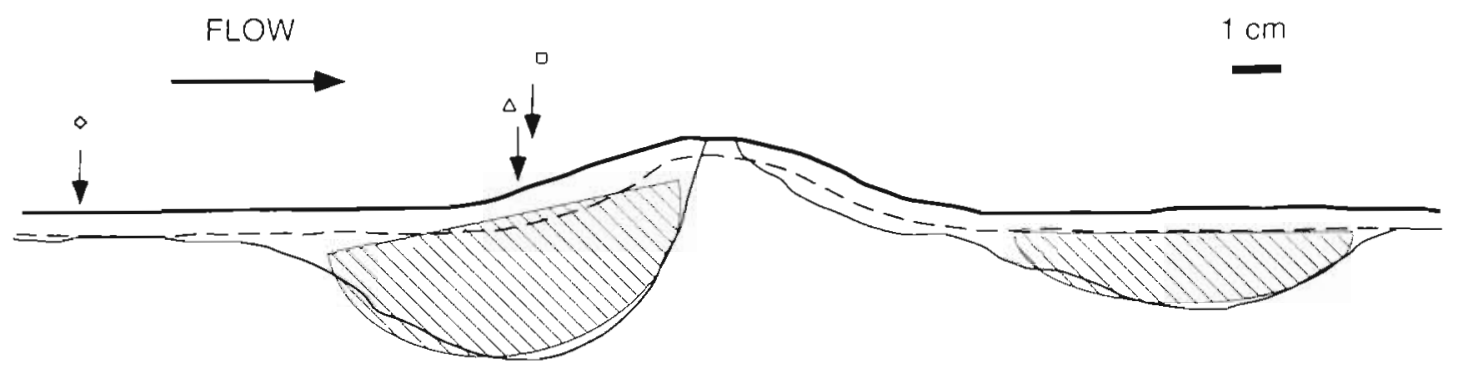

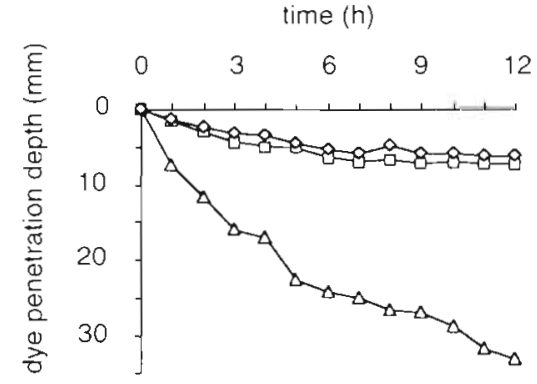

Sea sediment did not produce topography structures of significant height or abundance. Therefore we constructed artificial structures of defined abundance and geometry by gently pouring sediment from a syringe onto the surface of the sediment ('artificial topography', for dimensions see Table 3).

Dye experiments. The contribution of advective pore water flow to sediment-water exchange was investigated using inert dye (Rhodamine WT, DuPont, Delaware, USA). Two flume experiments, one with 'impermeable' and one with 'permeable' sediment, were set up with otherwise identical flow conditions $\left(5.2 \pm 0.8 \mathrm{~cm} \mathrm{~s}^{-1}\right)$ and topography. In these experiments, a sediment ripple aligned perpendicular to the flow and extending across the whole width of the core represented the surface topography. The dimensions were such that the cross-section visible at the transparent walls of the flume (height $14 \mathrm{~mm}$, base length $85 \mathrm{~mm}$ ) was directly comparable to that of the mounds used in the oxygen utilisation experiments (see below). Velocity and penetration depth (precision $\pm 1 \mathrm{~mm}$ ) of the red solute front in the 2 sediments was calculated from enlarged photographs taken through the transparent side walls of the flumes at $1 \mathrm{~h}$ intervals over a period of $12 \mathrm{~h}$

We calculated sediment volumes $\left(V_{\mathrm{s}}\right)$ affected by stained pore water flow for mounds of $14 \mathrm{~mm}$ height and an abundance of 24 mounds $\mathrm{m}^{-2}$. We assumed the geometry of 2 rotational ellipses up- and downstream of a mound [Fig. 1; $V_{\mathrm{s}}=0.5 \mathrm{~V}=(2 / 3) \pi a b^{2}$, with the volume $(V)$ of the ellipses, the half-axes $(a)$, and thus the longitudinal rotation axes (2a) oriented along the axes of the flume, and the axes (b) equal to the pene-
Fig. 1. Penetration depth of Rhodamine WT dye in coarse (-) and fine sandy sediment (---) due to advection and diffusion. (flow $5 \mathrm{~cm} \mathrm{~s}^{-1}$; experimental duration $12 \mathrm{~h}$ ). Images are superimposed for comparison. Graph shows penetration of the dye front in the smooth surface $(\diamond)$ (average of 8 measurements pooled from fine and coarse sediment) and at an upstream position at the topography [for fine ( $\square$ ) and coarse $(\Delta)$ sediment]. See 'Methods' for details. Shaded areas show rotational half-ellipses used for calculation of sediment volumes and grain surfaces affected by stained pore water flow

tration depth of the dye]. Due to the error associated with the measured distances $( \pm 0.1 \mathrm{~cm})$ the result is affected by $3 \%$.

TOU measurements. The effect of flow on TOU in the 2 sediment types was investigated by increasing the flow velocity between consecutive runs of 6 experiments (Expts 1.1 to 1.4, 2.3 and 2.4; Table 2). Each experiment included 4 to 8 runs. A $12 \mathrm{~h}$ period was allowed to elapse between the changing of the flow velocity at the end of one run and the start of TOU measurements in the next one.

Prior to each TOU measurement, the water was kept above $90 \%$ air saturation by bubbling with air. The flumes were closed with acrylic lids and water was added until no air was left in the system. Light penetration into the flumes was prevented to avoid interfering photosynthetic activity. The decline in oxygen concentration over a $4 \mathrm{~h}$ period which began $2 \mathrm{~h}$ after sealing of the flume was used to calculate TOU. Typically the concentration declined from, e.g., 190.9 to 183.4 $\mu \mathrm{M}$ within $4 \mathrm{~h}$

Based on the temperature variations and the accuracy of the sensor readings, we assigned an accuracy of $\pm 1.5 \mathrm{mmol}$ oxygen $\mathrm{m}^{-2} \mathrm{~d}^{-1}$ to TOU values reported. We measured the oxygen consumption of the flume system including collimators, acrylic walls, etc., in a control run with the sediment core covered by a thin acrylic sheet in order to prevent oxygen supply to the sediment. In this case, the oxygen consumption was 3 mmol oxygen $\mathrm{m}^{-2} \mathrm{~d}^{-1}$.

With the coarse sediment we conducted 2 experiments (Expts 1.1 and 1.2) with topography structures constructed by the infauna and 1 experiment (Expt 1.3) 
with artificial topography. Control experiments with smooth sediment surfaces ('smooth control') were performed without topography and without macrofauna present (Expts 1.4 and 2.4). The macrofauna was removed by sieving (coarse sediment only). To eliminate the topography, the sediment surfaces were carefully smoothed with an acrylic sheet (roughness height $\leq 0.3 \mathrm{~mm}$ ). Finally, in order to compare the effect of sediment permeability in the presence of topography, artificial mounds were built on the fine sediment (Expt 2.3).

In order to test the response of the 2 sediment types to an addition of particulate organic carbon (POC), we conducted 4 experiments (Expts 1.5 to 1.7 and 2.5) at a constant flow velocity of $8 \mathrm{~cm} \mathrm{~s}^{-1}$ and with the same salinity and temperature in both flumes (34\% and, $16^{\circ} \mathrm{C}$, Table 3). A suspension of living planktonic algae (Dunaliella sp., not washed) from a batch culture was added to the flumes and TOU measured over the following $6 \mathrm{~d}$

In Expt 1.6, the smoothed coarse sediment core was covered with an acrylic sheet, which made the deposition of algae on the sediment impossible and served as a measure of algal oxygen consumption in the water. In Expt 1.7, we measured the TOU response to the deposition of POC on a smooth surface of the coarse sediment. In parallel experiments (Expts 1.5 and 2.5), both sediment types with the same artificial topography (Table 3) were subjected to identical additions of algae in order to directly compare the effects of topography on POC degradation. The impact of advective pore water flow was assessed from oxygen microprofiles determined prior to and after Expts 1.5 and 2.5.

We measured chlorophyll a (chl a) content (5 replicates; Jeffrey \& Humphrey 1975) and the C:N ratio (Carlo-Erba Model 1500) in $0.4 \mu \mathrm{m}$ filtrates from water samples to assess the amount of algal material in suspension (Expts 1.5 to 1.7 and 2.5, Table 3). A C:N ratio of 15 found in our fresh algae suspensions was used to convert chl a measurements to carbon-equivalents.

\section{RESULTS}

\section{Sediment type and advective water flow}

The 2 sandy sediments used for the comparison had similar water and organic carbon contents, but differed in grain size distribution and permeability (Table 1). Calculated grain surface areas were $208 \mathrm{~cm}^{2} \mathrm{~cm}^{-3}$ wet sediment in the fine North Sea sand and $115 \mathrm{~cm}^{2} \mathrm{~cm}^{-3}$ in the coarse Giglio sand.

The experiments with Rhodamine WT dye demonstrated advective transport of water in the coarse sediment. Intrusion of stained water is depicted in Fig. 1 by
Table 4. Sediment volumes and corresponding total sand grain surfaces affected by advection and diffusion in the 2 sediment types (all numbers given for surfaces with 24 mounds of $14 \mathrm{~mm}$ height per $\mathrm{m}^{2}$ ) based on intrusion of dye after 12 h of flow at $5 \mathrm{~cm} \mathrm{~s}^{-1}$

\begin{tabular}{|c|c|c|c|c|}
\hline & \multicolumn{4}{|c|}{ Sediment affected by dye intrusion } \\
\hline & \multicolumn{2}{|c|}{ Fine } & \multicolumn{2}{|c|}{ Course } \\
\hline & Diffusive & Advective & Diffusive & Advective \\
\hline $\begin{array}{l}\text { Volume } \\
\left(\mathrm{cm}^{3} \mathrm{~m}^{-2}\right)\end{array}$ & 6100 & 68 & 7200 & 2187 \\
\hline $\begin{array}{l}\text { Grain surface } \\
\left(\mathrm{m}^{2} \mathrm{~m}^{-2}\right)\end{array}$ & 127 & 0.7 & 83 & 25 \\
\hline
\end{tabular}

a superimposed image derived from the view through the acrylic wall in 2 tracer experiments. In the more permeable coarse sediment, the red colour had penetrated to a maximum of $32 \mathrm{~mm}$ in the upstream region of the topography structure after $12 \mathrm{~h}$ of exposure to a free flow of $5.2 \pm 0.8 \mathrm{~cm} \mathrm{~s}^{-1}(\mathrm{n}=11)$. In the smooth areas of the coarse bed, transport of dye reached a depth of $7.2 \pm 1.2 \mathrm{~mm}(\mathrm{n}=4)$. Accordingly, the calculation of sediment volume affected by advective flow was $2187 \mathrm{~cm}^{3}$ relative to a sediment volume of $7200 \mathrm{~cm}^{3}$ stained predominantly due to diffusion (at 24 mounds $\mathrm{m}^{-2}$ ) (Table 4). Upwelling of reduced clear pore water from below was marked by the discontinuous distribution of dye on the topography

In the fine-grained sand, penetration of dye was slightly higher upstream of the topography $(6.9 \mathrm{~mm})$ as compared to the smooth surface areas $(6.1 \pm 0.6 \mathrm{~mm}$, $\mathrm{n}=6$ ) after $12 \mathrm{~h}$ at a flow of $5.2 \mathrm{~cm} \mathrm{~s}^{-1}$. Here the sediment volume affected by advective flow was $68 \mathrm{~cm}^{3}$ $\mathrm{m}^{-2}$, which is considerably less than the volume stained predominantly by diffusive transport of dye.

\section{Total oxygen utilisation}

The results of the 33 flume runs are summarised in Fig. 2. TOU increased with boundary flow velocity in the permeable sediment when surface topography was present. Slopes of the regression lines in all 3 cases are significantly different from zero (Student's $t$-test: Expt 1.1, $\mathrm{r}=0.842, \mathrm{p}=0.1$; Expt 1.2, $\mathrm{r}=0.652, \mathrm{p}=0.1$; Expt 1.3, $r=0.879, p=0.005$ ). The increase of TOU with flow for a $10 \mathrm{~cm} \mathrm{~s}^{-1}$ velocity increment amounted to 63,55 , and $167 \%$ in Expts 1.1, 1.2, and 1.3 respectively. On average, TOU increased by $91 \pm 23 \%$ ( $\mathrm{r}=$ 0.782 , pooled data, $n=20$ ). There was a difference in topography structure between runs with coarse sediment and natural topography (Expts 1.1 and 1.2) on the one hand and those with artificial topography (Expt 1.3) on the other hand. Burrowing activity of the 

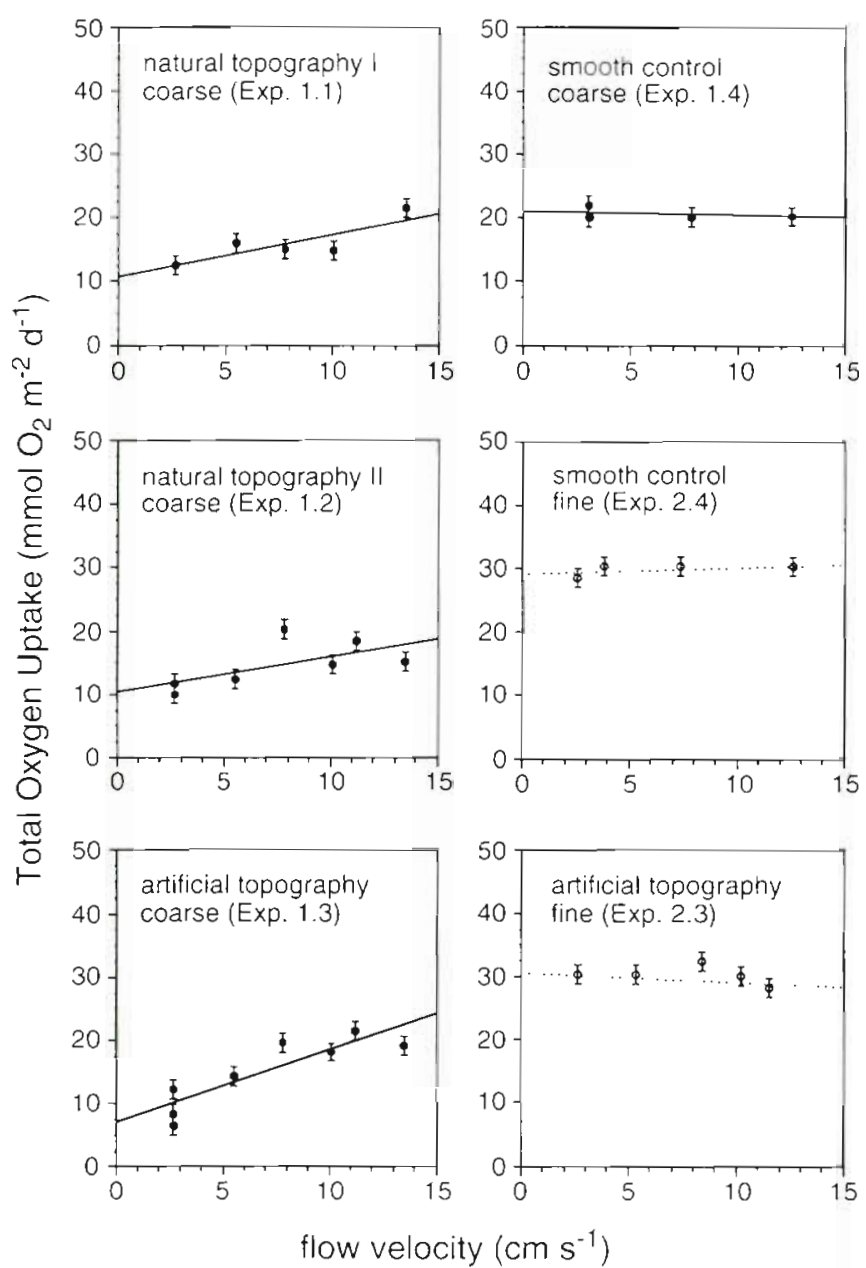

Fig. 2. Total. oxygen utilisation (TOU) as a function of flow velocity in sediment cores with different permeabilities and surface topographies. The column on the left includes experiments where advective transport of pore water makes TOU a variable of flow. On the right sediments show no flow-dependency, either because topography structures are lacking or the sediment permeability is too low to show effects of flow

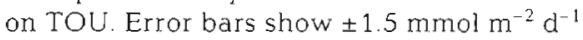

infaunal organisms added mounds in the latter experiment (Table 3), some of considerably larger dimensions than the artificial ones. Comparing the intercepts of regression lines, a higher value at 0 -flow velocity was observed in Expt 1.4, after removal of the macroorganisms and mixing of the sediment during sieving. than in Expts 1.1 to 1.3 .

There was no detectable flow effect on TOU in the smooth control experiment using coarse sand. The fine sediment core exhibited no dependence of TOU on flow, either with or without topography added.

Oxygen penetrating into the smooth sediment surfaces predominantly by diffusion reached a depth of 4.2 to $4.4 \mathrm{~mm}$ on average. The oxygen microprofiles measured at 3 different flow velocities did not show a significant dependence on flow velocity in either sediment type (Table 5, Fig 3). Though oxygen penetration depths were similar, oxygen concentrations were higher in the upper millimetre below the sedimentwater interface of the coarse sand compared to the fine sediment. Concentration gradients and penetration depths of oxygen are given in Table 5 .

At a constant flow velocity of $8 \mathrm{~cm} \mathrm{~s}^{-1}$ and with POC addition, oxygen penetration depth in the coarse sediment decreased by $5 \mathrm{~mm}$ in the upstream region of the mounds within $6 \mathrm{~d}$, from 19 to $14 \mathrm{~mm}$ (Fig. 4a). In the fine sand, oxygen penetration decreased by only $1 \mathrm{~mm}$ to $6 \mathrm{~mm}$ in the corresponding locations (Fig. 4c). No significant changes were recorded in the smooth surface control oxygen profiles of either sediment type (Fig. $4 \mathrm{~b}, \mathrm{~d}$ ).

TOU increased in each of the experiments (Fig. 5). An addition of POC to the flume without deposition on the sediment surface (control Expt 1.6, sediment covered with an acrylic sheet) lead to a short response lasting $3 \mathrm{~d}$ only. Oxygen consumption in the water, presumably by algal respiration, increased TOU by a total of $6 \mathrm{mmol} \mathrm{O}_{2} \mathrm{~m}^{-2}$. In contrast, algae settling on a smooth sediment surface (Expt 1.7) caused an increase in $\mathrm{O}_{2}$ utilisation lasting $4 \mathrm{~d}$ with a total of $23 \mathrm{mmol}$ $\mathrm{O}_{2} \mathrm{~m}^{-2}$.

\section{normalised oxygen concentration}

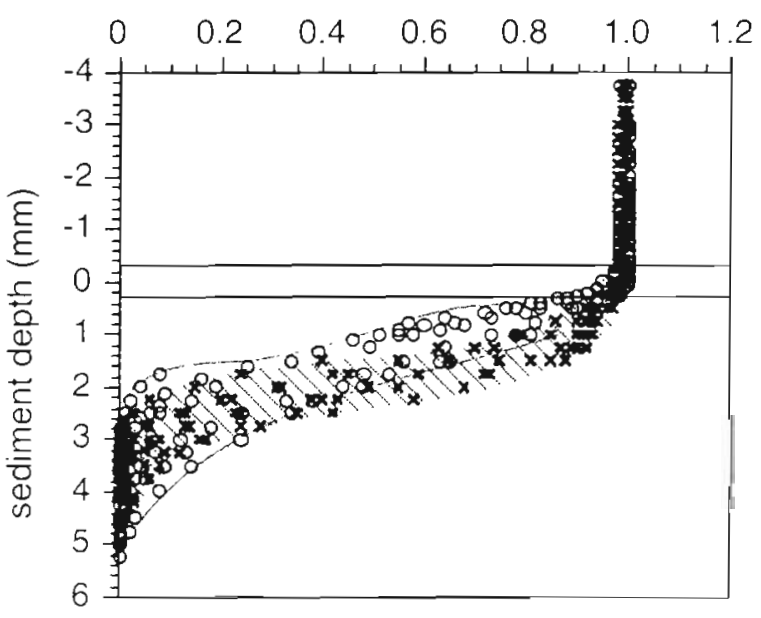

Fig. 3. Comparison of the oxygen profiles in smooth surface of coarse ( $x$, hatched area) and fine $(0$, outlined area) sediments at a flow velocity of $10 \mathrm{~cm} \mathrm{~s}^{-1}$ (Expts 1.4 and 2.4). Seven concentration profiles are given for each sediment type. For better companson, concentrations are normalised to the overlying water $\mathrm{O}_{2}$-concentration, which was $>90 \%$ air saturation in each case. Horizontal lines indicate the position of the sediment-water interface withn $\pm 300 \mu \mathrm{m}$, as determined independently by visual inspection and by the first decline in concentrations by more than $5 \%$ of the values in the water column 
Table 5. Steepest oxygen concentration gradient $( \pm \mathrm{SD})$ and penetration depth of oxygen $( \pm S D)$ at smooth sediment surfaces of fine and coarse sand. The values are given for 3 different flow conditions and as average values of all oxygen microprofiles measured; $\mathrm{n}=$ number of measurements. Dye penetration depths at smooth sediment surfaces measured after $12 \mathrm{~h}$ at a flow velocity of $5 \mathrm{~cm} \mathrm{~s}^{-1}$ are given for companson (see Fig. 1)

\begin{tabular}{|c|c|c|c|c|}
\hline & \multicolumn{3}{|c|}{ Flow velocities } & \multirow[t]{2}{*}{ Average } \\
\hline & $3 \mathrm{~cm} \mathrm{~s}^{-1}$ & $6 \mathrm{~cm} \mathrm{~s}^{-1}$ & $10 \mathrm{~cm} \mathrm{~s}^{-1}$ & \\
\hline \multicolumn{5}{|l|}{ Coarse } \\
\hline Gradient $\left(\mu \mathrm{M} \mathrm{mm}^{-1}\right)$ & $0.95 \pm 0.18$ & $0.85 \pm 0.20$ & $1.15 \pm 0.11$ & $1.05 \pm 0.30$ \\
\hline Penetration (mm) & $4.2 \pm 0.6$ & $5.3 \pm 1.1$ & $3.8 \pm 0.5$ & $4.4 \pm 1.0$ \\
\hline$n$ & 6 & 5 & 7 & 18 \\
\hline Dye penetration ( $\mathrm{mm}$ ) & \multicolumn{3}{|c|}{$7.2 \pm 2.8$} & \\
\hline \multicolumn{5}{|l|}{ Fine } \\
\hline Gradient $\left(\mu \mathrm{M} \mathrm{mm}^{-1}\right)$ & $1.09 \pm 0.27$ & $1.18 \pm 0.15$ & $1.30 \pm 0.28$ & $1.18 \pm 0.26$ \\
\hline Penetration (mm) & $4.6 \pm 0.3$ & $4.1 \pm 0.4$ & $3.9 \pm 0.9$ & $4.2 \pm 0.7$ \\
\hline $\mathrm{n}$ & 5 & 5 & 7 & 17 \\
\hline Dye penetration $(\mathrm{mm})$ & \multicolumn{3}{|c|}{$6.1 \pm 0.6$} & \\
\hline
\end{tabular}

In Expts 1.5 and 2.5, the algae settled within $5 \mathrm{~d}$, as traced by declining chl a concentrations in the water column, equivalent to an organic matter addition of

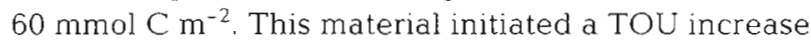
which lasted longer than the $6 \mathrm{~d}$ period allotted for measurements. A minimum estimate from the data in Fig. 5 of the additional TOU is $30 \mathrm{mmol} \mathrm{O}_{2}$ $\mathrm{m}^{-2}$ in the fine and $50 \mathrm{mmol} \mathrm{O}_{2} \mathrm{~m}^{-2}$ in the coarse sediment.

\section{DISCUSSION}

Flow plays a major role in controlling flux of oxygen and other solutes across the sediment-water interface (Pamatmat 1971, Bowmann \& Delfino 1980). The transformation of organic matter in cohesive sediments is limited by diffusion as the dominant transport process of electron acceptors available for the remineralisation of organic matter by bacteria (Froelich et al. 1979). Biological and hydrodynamical mechanisms enhancing solute fluxes across the sediment-water interface thus increase the potential for mineralisation (Aller 1980, Huettel \& Gust 1992, Webster \& Taylor 1992, Forster \& Graf 1995).

Ziebis et al. (1996) investigated the distribution of oxygen in the same coarse sediment in relation to the
Fig. 4. Penetration of oxygen in coarse (a, $b_{i}$ Expt 1.5) and fine (c, di Expt 2.5) sandy sediment at selected sites before $(+)$ and $6 \mathrm{~d}$ after $(\bullet)$ addition of particulate organic carbon. The profiles in (a) and (c) ('topography') were taken at the site of maximum penetration depth of oxygen upstream of the mound; those in (b) and (d) are from smooth control areas in the same flume
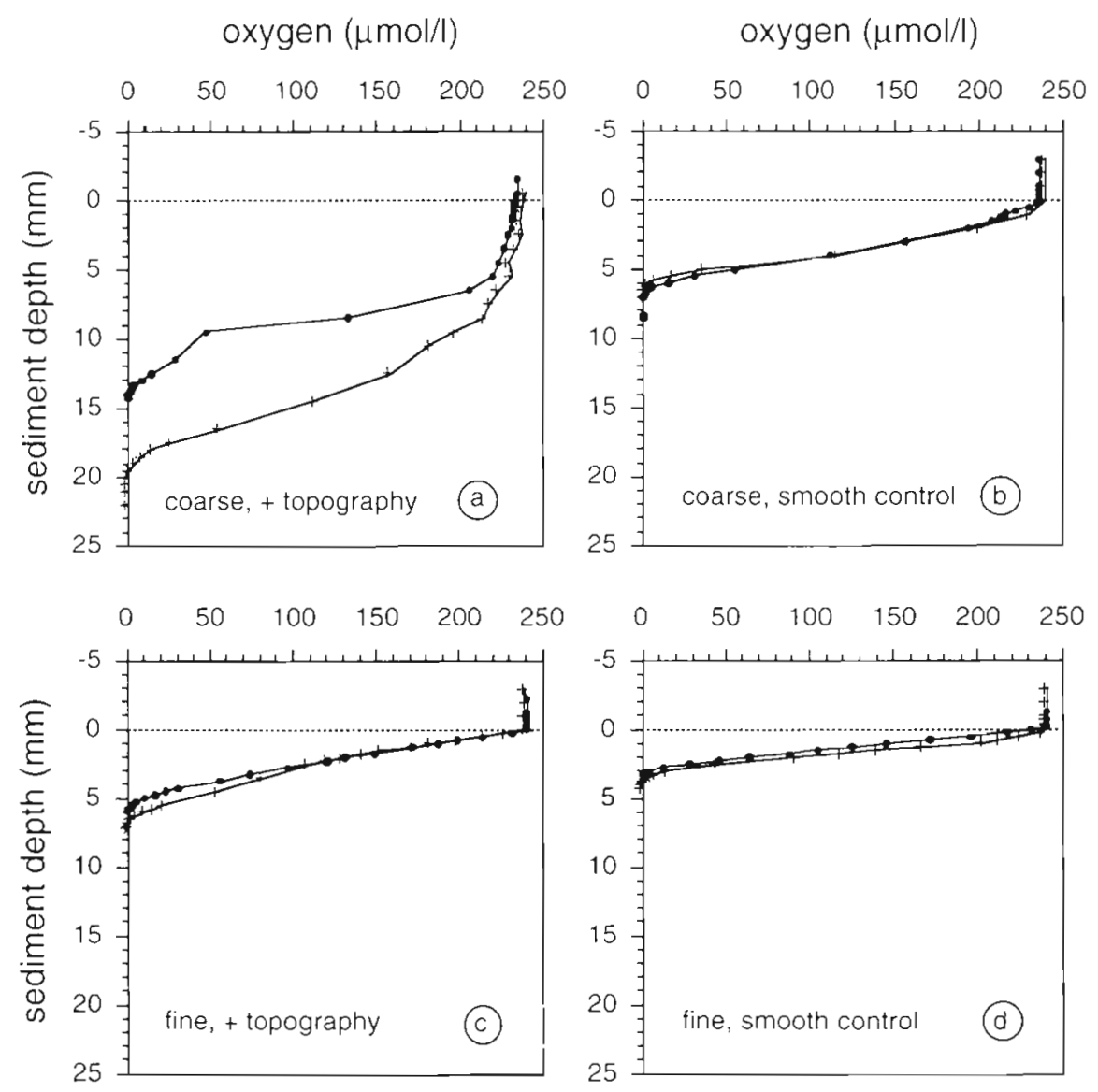

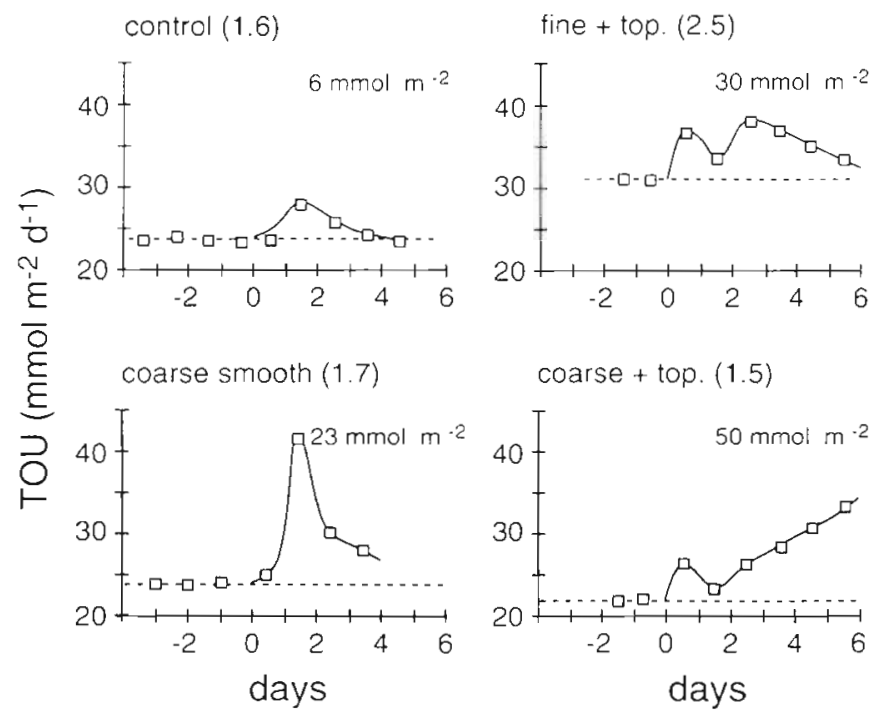

Fig. 5. Time courses of TOU after addition of particulate organic carbon (POC) at Day 0 . Readings were taken once a day with an accuracy of $\pm 1.5 \mathrm{mmol} \mathrm{O}_{2} \mathrm{~m}^{-2} \mathrm{~d}^{-1}$, as indicated by the dimension of the squares. (-.-) Level of TOU assumed without POC addition. Additional TOU due to POC is calculated by integrating the area between both lines (given in mmol $\mathrm{O}_{2} \mathrm{~m}^{-2}$ in each graph). Expt 1.6 (control): sediment covered with acrylic at $t=0$ in order to prevent deposition of algae on the sediment; Expt 1.7: deposition of algae on the smooth surface of the coarse sand; Expt 2.5: effect of deposition of algae on the fine sediment; Expt 1.5: combined effect of advective oxygen transport and POC input in permeable coarse sand

mechanism driving pore water flow. They demonstrated dramatic changes of oxygen penetration depth with changing flow velocity. The present study focused on the combined effect of surface topography interacting with boundary layer flow on the utilisation of oxygen (TOU)

\section{The advective flow}

A linear increase of TOU was observed in the permeable sediment with surface topography present and flow velocities varying between 2 and $14 \mathrm{~cm} \mathrm{~s}^{-1}$ (Fig. 2). This increase is a result of a combined effect of permeability and topography.

Permeability differed by 1 order of magnitude between the coarse and the fine sediment. The effect of permeability on advective flow is apparent in the comparison of fine and coarse sediments of regions adjacent to the topography structure (Fig. 1). The higher permeability of the coarse sand $\left(k=5 \times 10^{-11}\right.$ $\mathrm{m}^{2}$ ) facilitated flushing of pore space in the vicinity of the topography (Figs. $1 \& 4$ ). Water penetrated $32 \mathrm{~mm}$ deep into the sediment, reaching sediment grain sur- faces that were left anoxic at the corresponding depth in the fine sediment. Judging from our experiments with flow of $5 \mathrm{~cm} \mathrm{~s}^{-1}, 30 \%$ more particle surface area was exposed to dye due to advection in the coarse sand than in the fine sand.

In contrast, for both coarse and fine sediment with a smooth surface, an increase in stained sediment with increasing flow speed was not detectable. In a smooth sediment surface, dye penetration depth after $12 \mathrm{~h}$ agreed with average $\mathrm{O}_{2}$-penetration in steady-state profiles for both sediment types (Table 5). Here, no effect of permeability can be seen in our data. With a permeability of $k=5 \times 10^{-12} \mathrm{~m}^{2}$ the fine sediment allowed for only little stained water intrusion in the upstream region of the topography structure (Fig. 1), which is documented in a $1 \mathrm{~mm}$ increase in dye penetration depth.

A calculation of the particle surface areas yields $127 \mathrm{~m}^{2} \mathrm{~m}^{-2}$ in the surface layer of the fine sandy sediment stained by dye $(6.1 \mathrm{~mm}$ penetration depth, $208 \mathrm{~cm}^{2}$ particle surface area per $\mathrm{cm}^{3}$ wet sediment). The corresponding value in the coarse sand was $83 \mathrm{~m}^{2}$ $\mathrm{m}^{-2}$ if no flow effects were present, assuming a dye penetration of $7.2 \mathrm{~mm}$ throughout the entire sediment surface $\left(7.2 \times 115 \mathrm{~cm}^{2} \mathrm{~cm}^{-3}\right)$. This indicates that there are potentially more bacteria present in the stained fine sand volumes, since most bacteria in sediments adhere to sediment particle surfaces (Meyer-Reil 1986)

However, due to topography-flow interaction, in a coarse permeable sediment the total grain surface in contact with oxic water from the sediment-water interface increases with flow, an effect not seen in the fine sediment. Exposed particle surface area in the coarse sand increased from $83 \mathrm{~m}^{2} \mathrm{~m}^{-2}$ at an assumed $0 \mathrm{~cm} \mathrm{~s}^{-1}$ to $108 \mathrm{~m}^{2} \mathrm{~m}^{-2}$ ( $83 \mathrm{~m}^{2}+25 \mathrm{~m}^{2}$ in advection areas) at $a$ flow of $5 \mathrm{~cm} \mathrm{~s}^{-1}$, if calculated for mounds of $14 \mathrm{~mm}$ height and an abundance of $24 \mathrm{~m}^{-2}$. At higher flow velocities or with more pronounced topography present, more particle surface area with associated bacteria is supplied with oxygen in a permeable bed than in a fine-grained sediment where diffusion is the limiting transport for oxygen from the overlying water.

We conclude that the sediment volume affected by advective pore water flows is negligible in the fine sediment. Pronounced advective transport can be observed in permeable sands, with the sediment volume and grain surface affected by advection increasing with flow velocity and topography present.

\section{Processes increasing TOU}

Flow influences the thickness of the diffusive boundary layer (DBL) of the sediment surface, making it a 
rate-limiting step in the interfacial transport of oxygen (Morse 1974, Gundersen \& Jorgensen 1990, Jørgensen \& Des Marais 1990). This effect is most pronounced in organic rich sediments where concentration gradients at the interface are steep.

In our oxygen microprofile measurements at the smooth sediment surfaces, the DBL could not be resolved with the spatial resolution used. We therefore could not detect an increase in oxygen gradient with flow velocity (Table 5), which indicates that these smooth surface areas did not contribute to the observed positive relation of TOU and flow above coarse sand in Expts 1.1, 1.2, and 1.3. In any case, we consider the effect of DBL depression on TOU minor in the relatively organically poor sands used.

There are, however, indications that the oxygen distribution at the smooth surface of the coarse sediment is different from that in fine sand. In Fig. 3, oxygen profiles taken from the coarse sediment show a slower decline of concentration with depth within the first millimetre of the sediment compared to the fine sediment profiles. Microprofiles of this sigmoidal shape reveal advective transport in the uppermost sediment layer (Revsbech et al. 1980), suggesting that flow in our flume systems potentially affected oxygen distribution even at the smooth surface of this coarse sediment. The extent to which oxygen flux at this surface is possibly enhanced due to flow is below the resolution of our TOU measurements. This issue awaits further investigation.

In contrast to the situation at the smooth surface, boundary flow significantly increases the volume of oxic sediment in the vicinity of surface topography as demonstrated by Ziebis et al. (1996). Those authors measured the distribution of oxygen in the advective flow zone of a mound and reported an additional oxic volume of $98 \mathrm{~cm}^{3}$ in the coarse sediment generated by a single mound (height $10 \mathrm{~mm}$, flow velocity $10 \mathrm{~cm} \mathrm{~s}^{-1}$ ). Adopting this number as the average effect of mounds in our experiments, we can calculate the increase in oxic sediment volume through flow and relate this volume to the oxic surface layer of $4.4 \mathrm{~mm}$ thickness present without flow. The estimated oxic volume increase, thus, lies between $49 \%(98 \times 22 / 4400)$ and $85 \%(98 \times$ $38 / 4400$ ) with 22 to 38 mounds $\mathrm{m}^{-2}$ present. The observed increase of 55 to $167 \%$ in TOU in the coarse sediment experiments is in the same range as the sediment volume flushed by oxic water through the advective flow. Deviations in size from the $10 \mathrm{~mm}$ standard mound assumed in the estimate above may account for the differences in the percentages, since sediment volume affected by advective flow increases exponentially with size of the mounds (Huettel \& Gust 1992). In our experiments, natural topography constructed by Callianassa truncata consisted of mounds of approximately 1 to $3 \mathrm{~cm}$ height and 3 to $6 \mathrm{~cm}$ diameter and funnels of 1 to $2 \mathrm{~cm}$ diameter and $1 \mathrm{~cm}$ depth.

In the fine sediment, an equivalent estimate yields an oxic volume increase $\leq 0.5 \%$, impossible to detect in our TOU measurements.

Other oxygen consuming processes included in the coarse sediment experiment with natural topography (Expts 1.1. 1.2, and 1.3) were irrigation and respiration by the shrimp. We did not measure these. However, their contribution to TOU is a function of the metabolism of the organisms themselves. Therefore a linearly increasing relation with flow velocity is not to be expected. Such a relation could be observed in the case of relict burrows flushed by boundary velocity induced secondary flows (Ray \& Aller 1985) or in the case of a faunal irrigation activity stimulated by boundary layer flow, a mechanism which to our knowledge has not been reported so far. TOU increased as a function of the abundance of mounds (Expts 1.1 and 1.2 vs Expt 1.3) with the same number of organisms present in all experiments. This further supports the conclusion that advective flushing of sediment interstices rather than irrigation was responsible for the positive relation of flow and TOU.

Reduced sediment expelled from the burrow may have contributed to the scatter observed in the TOU data of both sediment types. However, burrowing activity can neither explain the observed linear increase in TOU with flow velocity nor differences between fine and coarse sediment.

TOU was in the range of $30 \mathrm{mmol} \mathrm{O} \mathrm{m}^{-2} \mathrm{~d}^{-1}$ for all measurements performed in the fine sediment core. In the coarse sediment TOU was lower (intercept at zero flow around $10 \mathrm{mmol} \mathrm{O}_{2} \mathrm{~m}^{-2} \mathrm{~d}^{-1}$ ). This observation is in agreement with a lower activity generally associated with low organic carbon content in sandy environments (Keil et al. 1994).

TOU in the coarse sediment control Expt 1.4, however, showed a higher level $\left(20 \mathrm{mmol} \mathrm{O}_{2} \mathrm{~m}^{-2} \mathrm{~d}^{-1}\right)$ after complete mixing of the sediment in order to remove the macrofauna. This mixing destroyed the stratification of bacterial distribution within the sediment and altered microbial activity. It also brought reduced sediment layers in contact with former surface sediment and possibly facilitated the oxidation of minerals, for instance $\mathrm{FeS}_{2}$, in the oxic layer. After a week of equilibration, TOU was measured and remained constant for $5 \mathrm{~d}$ at a high level, reflecting a new steady state of microbial processes. An important result is that oxygen flux was not a function of flow velocity.

In addition to increasing the oxic sediment volume, the advective flows depicted in Fig. 1 also enlarge the interface between oxic and anoxic sediment and channel a flow of reduced pore water upwards to the sediment surface (Huettel et al. 1996b, Ziebis et al. 1996). 
The latter mixes with the recirculating water of the flume, and an unknown amount of oxygen, equivalent to the reduced solute content of the upwelling water, is utilised. Presumably the contribution of upwelling pore water was of minor importance in our experimental set-up, with relatively little anaerobic activity at low sediment carbon content. This is also indicated by the agreement between the sediment volume flushed and the TOU increase. Processes at oxic-anoxic interfaces and effects of upwelling reduced pore water may be more pronounced in sediments rich in organic carbon.

Within the limits of accuracy, the TOU increase observed in the coarse sediment experiments is related to the oxic volume enlargement of sediment at the topography structures. This result is in agreement with oxygen consumption being a 0 -order process with respect to oxygen at concentrations above $10 \mu \mathrm{M}$ (Hao et al. 1983, Rasmussen \& Jørgensen 1992). With TOU dependent on advective interfacial pore water flow, 1 more mechanism for enhanced $\mathrm{O}_{2}$-uptake is presented. The result indicates that in situ oxygen utilisation data from sandy beds have to be interpreted in context with the flow conditions and topography maintained during the measurements.

\section{Effects of fresh carbon input}

Oxygen is consumed at higher rates in sediments that are rich in degradable organic material and after sedimentation events (Graf et al. 1983, Hansen \& Blackburn 1992). In our TOU experiments, we assumed the organic matter to be associated with particle surfaces in both sediment types, that is, a distribution as a monolayer on the particles (Mayer et al. 1985, 1988). However, in most cases of high fresh carbon input, dissolved organic carbon and organically rich large particles are dominant in the pool of carbon, and a fixed relation of organic carbon to particle surface area does not exist (Mayer 1989).

The experiments showed that oxic respiration in the flumes is enhanced when POC deposits on the sediment. A minor increase in oxygen consumption owing to the presence of algae in the flume water $\left(6 \mathrm{mmol} \mathrm{O}_{2}\right.$ $\mathrm{m}^{-2}$ ) is maintained for a short time only and cannot account for the TOU responses obtained in the subsequent experiments. POC deposited on the smooth surface of the coarse sediment (Expt 1.7) was available for aerobic processes with a predominantly diffusive supply of oxygen and caused $23 \mathrm{mmol} \mathrm{O}_{2} \mathrm{~m}^{-2}$ of additional TOU. A similar value was obtained in fine sediment with topography present (Expt 2.5,30 $\mathrm{mmol} \mathrm{O}_{2} \mathrm{~m}^{-2}$ ), but the highest additional consumption of oxygen clearly resulted in the combination of POC addition and advective oxygen supply (Expt 1.5, $50 \mathrm{mmol} \mathrm{O}_{2} \mathrm{~m}^{-2}$ ).
Increased oxygen utilisation may reflect decomposition of a certain percentage of the carbon input and is calculated assuming complete aerobic respiration and a respiratory ratio of 0.85 (moles of $\mathrm{CO}_{2}$ evolved per mole $\mathrm{O}_{2}$ consumed; Schmidt-Nielsen 1983). Additional oxygen utilised in our experiments thus corresponds to $71 \%$ in the coarse and $43 \%$ the fine sediment of the carbon added to the flumes. This indicates that particulate carbon is remineralized quite effectively under flow conditions and more so in the coarse sediment. Monitoring oxygen uptake in an algae addition experiment, Hansen \& Blackburn (1992) found an equivalent of less than $20 \%$ of the carbon added within $5 \mathrm{~d}$.

The amount of POC added $\left(60 \mathrm{mmol} \mathrm{C} \mathrm{m} \mathrm{C}^{-2}\right)$ is roughly equivalent to twice the daily export production to the sediment in the North Sea, which was given

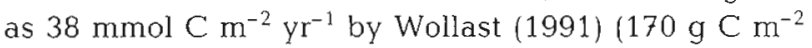
$\left.\mathrm{yr}^{-1}\right)$. Sedimentation events in the field and additions in bloom simulation experiments often involve much higher masses of carbon than our addition. Hansen \& Blackburn (1992) added algae equivalent to $686 \mathrm{mmol}$ $\mathrm{C} \mathrm{\textrm {m } ^ { - 2 }}$ to incubated sediment cores, triggering a response in increased oxygen uptake lasting $13 \mathrm{~d}$. From an addition experiment with Phaeocystis spp. equivalent to $2000 \mathrm{mmol} \mathrm{C} \mathrm{m}{ }^{-2}$, van Duyl et al. (1992, 1993) reported $10 \mathrm{~d}$ of increased bacterial production. Graf et al. (1983) observed a bloom of $960 \mathrm{mmol} \mathrm{C} \mathrm{m}^{-2}$ settling in the field and a response in heat production in the sediment indicating complete utilisation of that bloom material within $13 \mathrm{~d}$.

In view of the relatively small additions, the duration of responses found in our addition experiments fits reasonably well. There is a further increase in TOU after $6 \mathrm{~d}$ in the coarse sediment such that the ratio of additional oxygen utilisation in the coarse over the fine sediment $\left(50 / 30 \mathrm{mmol} \mathrm{O}_{2} \mathrm{~m}^{-2}\right.$ ) would have been even higher after some more days.

When particulate carbon in the form of algae deposits on the sediment, cells release exudates and open by lysis or due to meiofauna feeding in the sand (Jensen 1987). Organic material, or components thereof, deposited on the sediment surface is also found in the sediment below (Graf 1992, Sun et al. 1994). Deposition of algae is increased in the vicinity of roughness elements (Yager et al. 1993) and advective pore water flow carries POC into the interstices at the sites of maximum oxygen penetration (Huettel et al. 1996b).

Intense oxygen respiration decreased the oxic sediment volume in our experiments, as reflected in $\mathrm{O}_{2}$ microprofiles (Fig 4). However, advective transport of oxygen remained constant throughout the experiments at $8 \mathrm{~cm} \mathrm{~s}^{-1}$ and oxygen was supplied at a rate sufficient to sustain an oxic sediment layer thicker than in the control area. A decrease in oxic volume after 
POC input implies that the rate of utilisation of oxygen per unit volume was stimulated to an even higher degree by advective transport in the presence of easily degradable carbon.

This is also evident in the comparison of coarse sediment with and without advective flow. Additional TOU in the coarse sediment was twice as high with topography and larger oxic sediment volume than without advection at the smooth sediment surface (Expt 1.5, $50 \mathrm{mmol} \mathrm{O} \mathrm{m}^{-2}$; Expt 1.7, $23 \mathrm{mmol} \mathrm{O}_{2} \mathrm{~m}^{-2}$ ). The data show that permeable sediments do have a high potential for aerobic oxygen utilisation.

\section{Implications for the field}

The predominant regions where advective transport of pore water oxygen potentially increases TOU are well-sorted sands with a low fine sand fraction in the intertidal and subtidal areas of the shelves. In shallow waters, permeable sediments, wave action, and currents contribute to flushing of the pore space (Riedl et al. 1972, Webster 1992, Webster \& Taylor 1992). Ripples of several centimetres in height develop on sandy grounds to tens of meters of water depth (Jenness \& Duineveld 1985) and to $>100 \mathrm{~m}$ depth due to heavy storms (Bedford \& Abdelrhman 1987). Abundant biogenic topography structures ranging from 20 to $120 \mathrm{~m}^{-2}$ are reported from many shelf and coastal sea beds (Cadée 1976, Suchanek 1985, Huettel 1988, Witbaard \& Duineveld 1989, Griffis \& Suchanek 1993, Ziebis et al. 1996).

Our experiments demonstrate that advective pore water flow is effective in stimulating sedimentary total oxygen utilisation with potential effects on nutrient and pollutant cycling (Kersten et al. 1988, Walsh 1991). When comparing our findings with the field, caution is warranted since the active mechanisms produce an overall effect on TOU which depends on a number of variables, among others abundance and type of topography, sediment permeability, and the carbon available for mineralisation. This paper probably describes minimum effects on TOU, since flushing of pore space increases with boundary layer flow velocity (Huettel \& Gust 1992), and velocities in our experiments were at the lower end of the possible range.

As indicated by the carbon addition experiment, advective transport enhances TOU even more when easily degradable organic carbon is available. A substantial portion of fresh carbon deposition is observed in episodic events, particularly in shallow marine environments (Smetacek et al. 1978, Graf et al. 1983, Walsh 1991, Graf 1992). The impact of boundary layer flow on remineralisation of carbon may therefore be more pronounced following sedimentation events. Moreover, organically poor sands apparently have a higher capacity for mineralisation than previously thought (Shum \& Sundby 1996). In these sediments, the combined effects of fresh carbon supply and advective oxygen transport provide a mechanism by which carbon utilisation is enhanced.

Acknowledgements. We thank S. Wenck for her help with the flume work and U. Bathmann for letting us use the CHN element analyser at the Alfred-Wegener Institute. We received valuable support from G. Herz, O. Gorg, V. Meyer, and G. Kothe from the machine and electronics shop during the early experimental phase with the flumes. Oxygen microelectrodes were skilfully constructed by A. Glud, A. Eggers, and G. Eickert from the microsensor group. We are grateful for $U$. Berninger's help both in the experiments and discussion of results. The manuscript benefited from constructive criticism of anonymous reviewers. This work was supported by the Max-Planck-Society, Germany.

\section{LITERATURE CITED}

Aller AC (1980) Quantifying solute distributions in the bioturbated zone of marine sediments by defining an average microenvironment. Geochim Cosmochim Acta 44: $1955-1965$

Aller AC (1983) The importance of the diffusion permeability of animal burrow linings in determining marine sediment chemistry. J Mar Res 41:299-322

Aller RC (1990) Bioturbation and manganese cycling in hemipelagic sediments. Phil Trans R Soc Lond A 331:51-68

Bedford KW, Abdelrhman M (1987) Analytical and experimental studies of the benthic boundary layer and their applicability to near-bottom transport in Lake Erie. J Great Lakes Res 13:628-648

Bowmann GT, Delfino JJ (1980) Sediment oxygen demand techniques: a review and comparison of laboratory and in situ systems. Water Res 14:491-499

Cadée GC (1976) Sediment reworking by Arenicola marina on tidal flats in the Dutch Wadden Sea. Neth $J$ Sea Res 10: $440-460$

Canfield DE, Jorgensen BB, Fossing H, Glud H, Gundersen J, Ramsing NB, Thamdrup B, Hansen JW, Nielsen LP. Hall POJ (1993) Pathways of organic carbon oxidation in three continental margin sediments. Mar Geol 133:27-40

Forster S, Graf G (1992) Contınuously measured changes in redox potential influenced by oxygen penetrating from burrows of Callianassa subterranea. Hydrobiol 235/236: $527-532$

Forster S, Graf G (1995) Impact of irrigation on oxygen flux into the sediment: intermittent pumping by Callianassa subterranea and 'piston-pumping' by Lanice conchilega. Mar Biol 123:335-346

Froelich PN, Klinkhammer GP, Bender ML, Luedtke NA, Heath GR, Cullen D, Dauphin P, Hammond D, Hartman B, Maynard $V$ (1979) Early oxidation of organic matter in pelagic sediments of the eastern equatorial Atlantic: suboxic diagenesis. Geochim Cosmochim Acta 43:1075-1090

Giles RV (1976) Theory and problems of fluid mechanics and hydraulics. McGraw-Hill, Düsseldorf

Glud RN, Gundersen JK, Jørgensen BB, Revsbech NP, Schulz HD (1994) Diffusive and total oxygen uptake of deepsea sediments in the eastern South Atlantic Ocean: in situ and laboratory measurements. Deep Sea Res 41 $1767-1788$ 
Graf G (1992) Benthic-pelagic coupling: a benthic view. Oceanogr Mar Bıol Annu Rev 30:149-190

Graf G, Schulz R, Pennert R, Mever-Reil LA (1983) Benthic response to sedimentation events during autumn to spring at a shallow-water station in the western Kiel Bight. Mar Biol 77:235-246

Griffis RB, Suchanek TH (1993) A model of burrow architecture and trophic modes in thalassinidean shrimp (Decapoda: Thalassinidea). Mar Ecol Prog Ser 79:171-183

Gundersen JK, Jørgensen BB (1990) Microstructure of diffusive boundary layers and the oxygen uptake of the sea floor. Nature 345:604-607

Hansen LS, Blackburn TH (1992) Effect of algal bloom deposition on sediment respiration and fluxes. Mar Biol 112: $147-152$

Hao OJ, Richard MG, Jenkins D (1983) The half-saturation coefficient for dissolved oxygen: a dynamic method for its determination and its effect on dual species competition. Biotechnol Bioeng 25:403-416

Huettel M (1988) Zur Bedeutung der Makrofauna für die Nährsalzprofile im Wattenmeer. PhD dissertation, Christian-Albrecht Universität, Kiel

HuetteI M, Forster S, Klöser S, Fossing H (1996a) Vertical migration in the sediment-dwelling sulfur bacteria Thioploca spp. in overcoming diffusion limitations. Appl Environ Microbiol 62:1863-1872

Huettel M, Gust G (1992) Impact of bioroughness on the interfacial solute exchange in permeable sediments. Mar Ecol Prog Ser 89:253-267

Huettel M, Ziebis W, Forster S (1996b) Flow-induced uptake of organic matter in permeable sediments. Limnol Oceanogr 41:309-322

Jeffrey SW, Humphrey GF (1975) New spectrophotometric equations for determining chlorophylls $a, b, c_{1}$, and $c_{2}$ in higher plants, algae and natural phytoplankton. Biochem Physiol Pflanzen 167:191-194

Jenness MI, Duineveld GCA (1985) Effects of tidal currents on chlorophyll a content of sandy sediments in the southern North Sea. Mar Ecol Prog Ser 21:283-287

Jensen P (1987) Feeding ecology of free-living aquatic nematodes. Mar Ecol Prog Ser 35:178-196

Jørgensen BB. Des Marais DJ (1990) The diffusive boundary layer of sediments: oxygen microgradients over a microbial mat. Limnol Oceanogr 35:1343-1355

Jørgensen BB, Revsbech NP (1985) Diffusive boundary layers and the oxygen uptake of sediments and detritus. Limnol Oceanogr 30:111-122

Jørgensen BB. Revsbech NP (1989) Oxygen uptake bacterial distribution and carbon-nitrogen-sulphur cycling in sediments from the Baltic Sea-North Sea transition. Ophelia $31: 29-49$

Keil RG, Tsamakis E, Fuh CB, Giddings JC, Hedges JI (1994) Mineralogical and textural controls of the organic composition of coastal marine sediments - hydrodynamic seperation using split-fractionation. Geochim Cosmochim Acta 58:879-893

Kersten $M$, Dicke $M$, Kriews $M$, Naumann $K$, Schmidt $D$, Schulz M. Schikowski M, Stelger M (1988) Distribution and fate of heavy metals in the North Sea. In: Salomons W. Bayne BL, Duursma EK, Forstner U (eds) Pollution of the North Sea-an assessment. Springer, Heidelberg, p 36-58

Kristensen E, Jensen MH, Andersen TK (1985) The impact of polychaete (Nereis virens Sars) burrows on nitrification and nitrate reduction in estuanne sediments. J Exp Mar Biol Ecol 85:75-91

Lindeboom HJ, Sandee AJJ, de Klerk-van der Driessche HAJ
(1985) A new bell jar/microelectrode method to measure changing oxygen fluxes in illuminated sediments with a microbial cover. Limnol Oceanogr 30:693-698

Marinelli RL (1994) Effects of burrow ventilation on activities of a terebellid polychaete and silicate removal from sediment pore waters. Limnol Oceanogr 39(2):303-317

Mayer LM (1989) The nature and determination of non-living sedimentary organic matter as a food source for depositfeeders. In: Lopez G, Taghon G, Levinton J (eds) Ecology of marine deposit feeders. Springer, New York, p 98-113

Mayer LM, Macko SA, Cammen L (1988) Provenance concentrations and nature of sedimentary organic nitrogen in the Gulf of Maine Mar Chem 25:291-304

Mayer LM, Raheim PT, Guenn W, Macko SA, Watling L, Andersen FE (1985) Biological and granulometric controls on sedimentary organic matter of an intertidal mudflat Estuar Coastal Shelf Sci 20:491-504

Means RE, Parcher JV (1964) Physical properties of soils Constable, London

Meyer-Reil LA (1.986) Measurements of hydrolytic activity and incorporation of dissolved organic substrates by microorganisms in marine sediments. Mar Ecol Prog Ser 31:143-149

Morse JW (1974) Calculation of diffusive fluxes across the sediment-water interface. J Geophys Res 79(33): $5045-5048$

Pamatmat MM (1971) Oxygen consumption by the sea bedIV. Shipboard and laboratory experiments. Limnol Oceanogr 16:536-550

Ray AJ, Aller RC (1985) Physical irrigation of relict burrows: implications for sediment chemistry. Mar Geol 62:371-379

Rasmussen $H_{1}$ Jørgensen BB (1992) Microelectrode studies of seasonal oxygen uptake in a coastal sediment: role of molecular diffusion. Mar Ecol Prog Ser 81:289-303

Revsbech NP (1989) An oxygen microsensor with a guard cathode. Limnol Oceanogr 34:472-276

Revsbech NP, Jørgensen BB (1986) Microelectrodes: their use in microbial ecology. In: Marshall KC (ed) Advances in microbial ecology. Plenum, New York, p 293-352

Revsbech NP, Jørgensen BB, Blackburn TH (1980) Oxygen in the sea bottom measured with a microelectrode. Science $207: 1355-1356$

Riedl R, Huang N, Machan R (1972) The subtidal pump: a mechanism of intertidal water exchange by wave action. Mar Biol 13:210-221

Rutgers van der Loeff MM (1990) Oxygen in pore waters of deep-sea sediments. Phil Trans R Soc Lond A 331:69-84

Schmidt-Nielsen K (1983) Animal physiology: adaptation and environment. Cambridge University Press, Cambridge

Shum KT, Sundby B (1996) Organic matter processing in continental shelf sediments - the subtidal pump revisited. Mar Chem 53:81-87

Smetacek V, von Bröckel K, Zeitschel B, Zenk W (1978) Sedimentation of particulate matter during a phytoplankton spring bloom in relation to the hydrographical regime. Mar Biol 47:211-226

Suchanek T (1985) Thalassinid shrimp burrows: ecological significance of the species-specific architecture. Proc 5th Int Coral Reef Congr, Tahiti, Antenne museum-PHE Moorea, French Polynesia, p 205-210

Sun MY, Aller RC, Lee C (1994) Spatıal and temporal distribution of sedimentary chloropigments as indicators of benthic processes in Long Island Sound. J Mar Res 52:149-176

Thamdrup B, Fossing HB, Jørgensen BB (1994) Manganese iron and sulfur cycling in a coastal marine sediment, Aarhus Bay, Denmark. Geochim Cosmochim Acta 58 $5115-5129$ 
van Duyl FC, Kop AJ, Kok A. Sandee AJJ (1992) The impact of organic matter and macrozoobenthos on bacterial and oxygen variables in marine sediment boxcosms. Neth J Sea Res 29:343-355

van Duyl FC, van Raaphorst W, Kop AJ (1993) Benthic bacterial production and nutrient sediment-water exchange in sandy North Sea sediments. Mar Ecol Prog Ser 100:85-95

Walsh JJ (1991) Importance of continental margins in the biogeochemical cycling of carbon and nitrogen. Nature 350 53-55

Webster IT (1992) Wave enhancment of solute exchange within empty burrows. Limnol Oceanogr 37:630-643

Webster IT, Taylor JH (1992) Rotational dispersion in porous media due to fluctuating flow. Water Resour Res 28:109-119

This article was submitted to the editor
Witbaard R, Duineveld GCA (1989) Some aspects of the biology and ecology of the burrowing shrimp Callianassa subterrariea (Montagu) (Thalassinidea) from the southern North Sea. Sarsia 74:209-219

Wollast $R$ (1991) The coastal organic carbon cycle: fluxes sources and sinks. In: Mantoura RFC, Martin JMR, Wollast $\mathrm{R}$ (eds) Ocean margin processes in global change. J Wiley \& Sons, London, p 365-382

Yager PL, Nowell ARM, Jumars PA (1993) Enhanced deposition to pits: a local food source for benthos. J Mar Res 51 $209-236$

Zlebis W, Huettel M, Forster S (1996) Impact of biogenic sediment topography on oxygen fluxes in permeable seabeds Mar Ecol Prog Ser 140:227-237

Manuscript first received: January 4, 1996 Revised version accepted: August 26, 1996 